\title{
ABSTRACTS
}

\section{Co-operative Government in South Africa's Post-apartheid Constitutions: Embracing the German Model?}

\author{
By Heinz Klug
}

This article explores the introduction of the notion of co-operative government in postapartheid South Africa in order to reflect upon the nature of constitutional borrowing and the impact of legal transplants that have been a common feature of post-cold war constitution-making processes around the world. Introduced to regulate the relationship between national, regional and local levels of government in post-apartheid South Africa, the idea of co-operative government and its constitutional form, including the constitutional principles for the distribution of legislative power between different levels of government, were borrowed primarily from the German Basic Law. While the form matches the Basic Law's pre-1994 Article 72(2) criteria, the interpretation of its meaning by the South African Constitutional Court has produced significantly different results, including a greater protection of regional powers. This difference in outcome is explained by adopting a contextual understanding of the role of legal transplants in constitution-making processes and under historical and political conditions prevailing in the receiving jurisdiction. Despite the seeming anomaly of similar texts but distinct outcomes, the article provides an example of how a comparative constitutional understanding must be based on a contextual analysis of the process of reception and on the limits implicit in the transfer of any particular model to a new context. Conversely, it offers a way for us to reflect on alternative understandings of the model and to explore why these options were foreclosed in the donating jurisdiction.

\section{The New Ethiopian Constitution and its effects on the legal order}

\section{By Heinrich Scholler}

This article is the second part of "The reception of the occidental law in Ethiopia" ["La réception du droit occidental en Ethiopie"] published in VRÜ 32 (1999), pp. 296. The author describes the history of the New Ethiopian Constitution of 1994 and points out its basic structure focussing on General Principles, Human Rights, Federal Structure and Jurisdiction. A closer look is taken to the changes in comparison with the old "Transitional 
Period Charter" attaching special importance to the occidental influences in the constitution-making process as well as its legal results. The author also comments on the real effects of this new Constitution on Ethiopia especially regarding the regulations on decentralisation.

\section{The African Charter on Human and Peoples' Rights between African Traditions and the Accordance with International law: the Example of Article $18 \mathrm{Sec}$ 1-3 of the African Charter}

\section{By Michaela Wittinger}

Contrary to the European and the American Convention on Human Rights, the protection of the family in the African Charter is characterised by economic rights (art. $18 \mathrm{sec} .1$ and 2 of the Charter) and the positive obligation of the State to support the family "which is the custodian of morals and traditional values recognized by the community". Not only for non African people it is open, what this formulation exactly means and which traditions are "recognized". The notion of the family as a "custodian" might be misused by States by excluding families which do not correspond with the traditional African structure from the protection provided for under art. 18. However, international human rights law and the fact that the African Charter underlines its integration into the international human rights system may guard women against infringement on their rights: art. 60 of the Charter allows to apply rules of universal and regional human rights instruments. Although art. 60 of the Charter raises questions of interpretation, it is possible to conclude that the term the African Commission "shall draw inspiration from" means a binding applicability of international instruments.

The African Charter requires explicitly the elimination of the discrimination of women and offers in particular the opportunity to widen the scope of the rights of women by making international law applicable (Art. $18 \mathrm{sec} .3$ of the Charter). Practices like polygamy, bride price and exclusion of women from selling and inheriting clan land violate the international interdictions of discrimination and the principles of equality and through art. $18 \mathrm{sec} .3$ also the African Charter.

The rights of women in the African Charter have a broad extent. Some provisions, however, concerning the references to international law, the significance of traditions and the role of the family in the African Charter are characterised by difficulties of interpretation. It will be upon the African Commission on Human and Peoples' Rights and of the future African Court on Human Rights to make use of the references of the African Charter to international law and to prevent individuals from extensive limitations of their freedom which could result from the term "African values and traditions" for the protection of the family rights and for the rights of women. 


\section{The legal status of an occupant of National Domain Lands in Cameroon}

\section{By Prosper Nkou Mvondo}

The cameroonian territory is made of large spaces of land which according to the Land Regulation (reform) of 1974 belong to nobody. But the State is charged by the same reform of the management of these lands (the lands of the National Domain). These lands are today occupied, and sometimes anarchically, by the people who are exploiting them for agriculture, pasture, accomodation. These people never write to the administration in order to obtain a status of legal occupant. However, one should not conclude that the one who is occupying the National Domain is illegal. The reform permitted to certain previous occupants to continue living on these lands, even without any legal status. Moreover, the 1974 reform grants them certain rights they can use in order to defend themselves against anyone, person or State, desirous to expulse them. However, the occupants without legal status should understand that their rights are limited. Anyway, their status is not the same with the status of those, who possess an official title given by the State; one day or the other, the occupant without a legal status is likely to loose the land. 